Barker, P.F., Camerlenghi, A., Acton, G.D., and Ramsay, A.T.S. (Eds.)

Proceedings of the Ocean Drilling Program, Scientific Results Volume 178

\section{DATA Report: CoMposite DepthS AND SPLICED SECTIONS FOR LEG 178 SITES 1095 ANd 1096, Antarctic Peninsula CONTINENTAL Rise'}

Peter F. Barker ${ }^{2}$

\begin{abstract}
During Leg 178, multiple advanced piston corer holes were drilled at four sites $(1095,1096,1098$, and 1099). Cores from the holes were correlated on board to produce composite depths and optimal spliced sections, but the time limitations aboard ship caused these to be preliminary. Recomputed composite depths for Sites 1098 and 1099 in Palmer Deep are reported elsewhere in this volume. This paper reports recomputed composite depths and spliced sections for Sites 1095 and 1096, located on a sediment drift on the continental rise of the Pacific margin of the Antarctic Peninsula. Limits on the validity of the spliced sections arise from limited multiple coverage and possibly from the effects of ocean swell.
\end{abstract}

\section{INTRODUCTION}

During Leg 178, cores were obtained from multiple holes at Sites 1095 and 1096, located on a sediment drift on the upper continental rise of the Antarctic Peninsula Pacific margin, mainly by use of the advanced piston corer (APC) at shallow subbottom depths. These two sites were selected to be complementary. Site 1096 lies on the proximal part of Sediment Drift 7, where sedimentation rates were known to be higher and thus where the younger part of the drift section could be sampled in expanded form. At the more distal Site 1095, the older part
${ }^{1}$ Barker, P.F., 2001. Data report: Composite depths and spliced sections for Leg 178 Sites 1095 and 1096, Antarctic Peninsula continental rise. In Barker, P.F., Camerlenghi, A., Acton, G.D., and Ramsay, A.T.S. (Eds.), Proc. ODP, Sci. Results, 178, 1-15 [Online]. Available from World Wide Web: <http://www-odp.tamu.edu/ publications/178_SR/VOLUME/ CHAPTERS/SR178_06.PDF $>$. [Cited YYYY-MM-DD]

${ }^{2}$ British Antarctic Survey, High Cross, Madingley Road, Cambridge CB3 OET, United Kingdom. p.barker@bas.ac.uk

Initial receipt: 28 August 2000 Acceptance: 13 March 2001

Web publication: 12 June 2001

Ms 178SR-219 


\section{P.F. BARKER}

of the drift is more accessible because the younger part is thinner. The sediment drifts contain a high-resolution record of the glacial state of the adjacent continent. At Site 1095, in $\sim 3842 \mathrm{~m}$ water depth, Hole 1095A was cored to 87.3 meters below sea floor (mbsf) with $99.1 \%$ recovery, Hole 1095B was cored to 570.2 mbsf (487.2-m cored section) with $79.2 \%$ recovery, and Hole $1095 \mathrm{D}$ was cored to $84.6 \mathrm{mbsf}$ with $93.3 \%$ recovery. At Site 1096, in $\sim 3152 \mathrm{~m}$ water depth, Hole 1096A was cored to 140.7 mbsf with $84.2 \%$ recovery, Hole $1096 \mathrm{~B}$ was cored to 260.6 mbsf with $80.5 \%$ recovery, and Hole $1096 \mathrm{C}$ was cored to 607.7 mbsf (409.9-m cored section) with $84.2 \%$ recovery.

The objective of multiple coring, a common Ocean Drilling Program (ODP) practice for paleoenvironmental studies usually involving triple coring, is to obtain a continuous sediment column that allows high-resolution sampling of undisturbed core. Coring depths are offset between holes so that the cores overlap. It is necessary then to produce an optimal "spliced" sediment column, usually aboard ship, to permit informed sampling, by correlating measurements of core physical properties between holes. A common composite depth scale is produced that allows the combination of selected sections of cores from different holes into an optimal spliced column. During Leg 178, not all sites were multiple cored and the main objectives were usually deeper in the drift. Only one site, Site 1098, was fully triple cored (see Acton et al., Chap. 5, this volume).

The effect of multiple coring at shallow subbottom depth at both of the sites reported here was duplication; very rarely were three cores available from which sections for splicing could be chosen. This degree of cover created more coring gaps than would have been likely with triple coring and restricted the choice of section. Some correlations between cores reported here are speculative, and a few are probably wrong; the spliced sections are inevitably less secure than for the usual triple-cored sites. Nevertheless, the greater time available postcruise and the opportunity to consider the available, less-than-perfect data sets at length have resulted in a revised calculation of mean composite depths and creation of spliced sections that are probably an improvement over the shipboard version (Shipboard Scientific Party, 1999b, 1999c).

\section{METHODS}

The production of composite depths and creation of spliced sections has been described in detail elsewhere (e.g., Hagelberg et al., 1992; Curry, Shackleton, Richter, et al., 1995; Jansen, Raymo, Blum, et al., 1996; Gersonde, Hodell, Blum, et al., 1999; Wang, Prell, Blum, et al., 2000). The data generally available were magnetic susceptibility (MS), gamma-ray attenuation (GRA) bulk density, natural gamma-ray activity, and compressional-wave ( $P$-wave) velocity, all from the whole-core multisensor track (MST) logger, and the color of the split core measured using a handheld Minolta color scanner. Three of the physical properties (MS, GRA density, and $P$-wave velocity) were measured at 2 -cm intervals; the fourth (natural gamma-ray activity) at $15-\mathrm{cm}$ intervals. The interval between Minolta color-scanner measurements on the split core was usually $5 \mathrm{~cm}$. The program SPLICER (version 2.1) was used to generate the composite depth scales and produce the spliced sections. This program allows comparison of data from several holes by overlaying and moving them vertically to optimize correlation. Cumulative optimal offset depths of cores are recorded in an "affine" table (the essence 
of which is extracted as Tables T1 and T2 for Sites 1095 and 1096, respectively), which may then be applied to each core to locate it on a common composite depth scale (meters composite depth [mcd]). The composite depth scale then forms the basis of selection of optimal "spliced" sections using most of the cores from each hole. Sections are selected to avoid core ends, unrecovered core, gas voids, disturbed core, presampled core (e.g., for interstitial water samples), and so forth. The correlated points that define the sections comprising the splice are tabulated in Tables T3 and T4 for Sites 1095 and 1096, respectively. The MS values for all three holes and for the spliced sections are plotted against depth to 90 mcd for Site 1095 in Figure F1 and to 270 mcd for Site 1096 in Figure F2. The spliced MS curve is color-coded to show the origin of each section used.

Tables T1, T2, T3, and T4 do not include the lower sedimentary succession at each site, which was only sampled in a single hole. Composite depths for these deeper cores are conventionally determined by applying to them the same offset as was attributed to the deepest core that had a counterpart core in another hole. Similarly, usually because of intervening poor recovery, some multiple-cored intervals cannot be tied unambiguously to those above them; here also, the offsets are kept the same as for the overlying core, and the splice below is "floating." In Tables T3 and T4, the uncorrelated core connections are labeled as "append" and the unlisted deeper cores are all similarly appended to the overlying spliced sections.

\section{DISCUSSION OF RESULTS}

The sedimentary successions at the two drill sites considered here differed mainly in sedimentation rate. There were only minor differences in lithology or measured physical properties between them, or in coring procedures. They therefore shared most correlation problems and are best considered together here.

The most useful physical property for correlating between cores was MS. The high terrigenous component and fine grain size of the sediments and high sampling rate assured MS variability, and the sediment remained largely (but perhaps not completely) free from diagenetic alteration. Occasionally, there was a dramatic difference in MS between the two cores, involving an extremely high value in one hole over a short interval, attributable to the influence of a single large high-MS glacial erratic. The second most valuable physical property was one of the chromaticity parameters $\left(\mathrm{a}^{*}\right.$ and $\left.\mathrm{b}^{*}\right)$ derived from the multispectral color scanner measurements (Shipboard Scientific Party, 1999a). The other available parameters showed lower variability or were less reliable. MS was used for almost all ties. Exceptions were the ties from Core $178-1095 \mathrm{D}-2 \mathrm{H}$ to $3 \mathrm{H}$ via Core $178-1095 \mathrm{~A}-3 \mathrm{H}$, for which no MST data were available, and the similar lack of MST data for most of Core 178$1095 \mathrm{D}-6 \mathrm{H}$. In both cases, chromaticity parameter $\mathrm{a}^{*}$ was used to effect the ties.

There are three minor exceptions to the general convention at Site 1096. Core 178-1096C-7X was planned as a short core to regain alignment after drilling $24 \mathrm{~m}$ but recovered $124 \%$ (7.11 $\mathrm{m}$ from a nominal cored length of $5.7 \mathrm{~m}$ ). The additional core is assumed here to have sampled the sediment above the nominal core top. Core 178-1096B$24 \mathrm{H}$ and cores below and Core 187-1096C-18X and cores below, both appended, are each shifted up by $1.0 \mathrm{~m}$ within the spliced sections to
T1. Offsets of cores, Holes 1095A, 1095B, and 1095D, p. 12.

T2. Offsets of cores, Holes 1096A, 1096B, and 1096C, p. 13.

T3. Splice tie points, Site 1095, p. 14.

T4. Splice tie points, Site 1096, p. 15 .

F1. Magnetic susceptibility for Holes 1095A, 1095B, 1095D, and the spliced sections, p. 8.

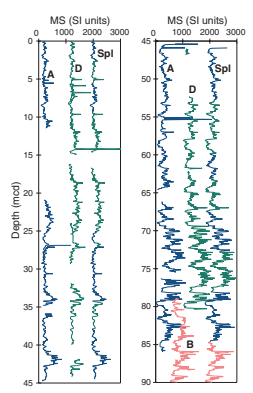

F2. Magnetic susceptibility for Holes 1096A, 1096B 1096C, and the spliced sections, p. 9.

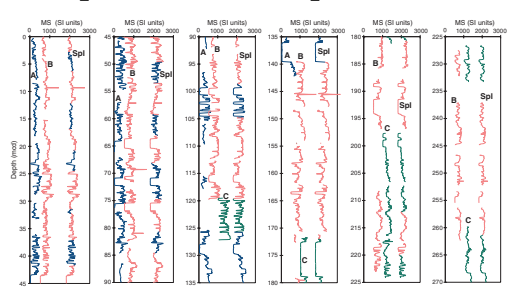




\section{P.F. BARKER}

avoid overlap associated with excessive recovery (see the changes in offset in Table T2).

The greater inherent uncertainty attached to correlations between only two cores, compared with correlations among three, has already been mentioned. In addition, there are other factors that affect or illustrate the reliability of the results that should be mentioned here.

First, SPLICER provides a numerical estimate of the correlation coefficient over a specifiable interval (usually maintained at $\pm 1 \mathrm{~m}$ ) surrounding each correlation. The utility of this estimate rests on the assumption that the cores being correlated are undeformed by the coring process or are deformed simply and to the same extent. However, it was clear that at Sites 1095 and 1096, the cores were deformed to different extents. It is now recognized that cores may be deformed by the coring process to different extents (e.g., Feary, Hine, Malone, et al., 2000; Wang, Prell, Blum, et al., 2000); the upper part of a single APC core may be expanded, whereas the lower part may be compressed. Ship heave, particularly in the upper part of a hole where the bottom-hole assembly (BHA) may not be fully supported by the sediments, may also be expected to affect both core recovery and distortion of the recovered core. In addition, a $10 \%$ expansion of the correlated meters composite depth (mcd) scale compared with the meters below seafloor (mbsf) scale is generally quoted and attributed by some to the elastic response of the sediment to release of ambient pressure (e.g., Moran, 1997).

Cumulative offsets at other ODP sites, although in many cases averaging $10 \%$ of the depth, can vary widely and may be dependent on compaction and lithology. Figure F3 shows the cumulative offset depths calculated for each core at Sites 1095 and 1096 as a putative measure of the quality of the correlation. They are neither uniform nor averaging 10\% expansion, and correlation at Site 1095 ends at $~ 85$ mbsf, whereas at Site 1096, multiple coring was continued intermittently to 260 mbsf in an effort to obtain a complete sample of the succession. The measured offsets at Site 1095 are cumulatively negative, reflecting nett compression rather than expansion. However, there is perhaps a similar change in offset with depth at both sites. Through the top 50-60 mbsf, offsets decline to a minimum from which there is a sharp rise (the slope at Site 1096 reaches a maximum of 8\%), reducing to $<1 \%$ at greater depth where correlation was less frequent. Some of the correlated cores below 160 mbsf at Site 1096 were obtained using the extended core barrel (XCB). The very different APC and XCB coring techniques would have interacted differently with the sediments, but this cannot explain the unusual results at both sites at shallower depth.

I propose an explanation for the apparent compression. Almost all the compression (negative offset gradient) occurs at shallow subbottom depth at both sites. All of Leg 178 drilling suffered from disturbance by swell; on the continental shelf, it was of sufficient amplitude to halt drilling. In deep water, it was less clearly noticeable and could be absorbed by the heave compensator above the rig floor once the BHA was fully supported by the sediments. However, for the uppermost four to five cores at each site, it is unlikely that the BHA was fully supported. It is possible that a mobile BHA, following ship heave to some extent, would have pumped sediment from the walls of the hole into the top of the space to be sampled in the next APC advance, compressing the "true" sediment section into $<100 \%$ and may similarly (though less time would have been available) have added to the base of the core by "repenetration" (e.g., Ruddiman et al., 1987; Robinson, 1990) after advance and withdrawal. A contributing factor might have been the very
F3. Core offsets applied at Sites 1095 and 1096, p. 10.

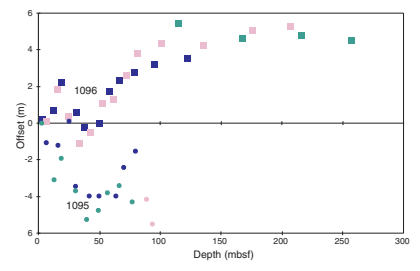




\section{P.F. BARKER}

fine grain size of the sampled sediments, which could have increased their mobility. Such factors as the change from in situ to laboratory pressure still have an effect, but at shallow depth this is assumed to be exceeded by the effect of ship heave. This explanation is offered in support of the contention that absence of the "expected" $10 \%$ expansion is not a sign of miscorrelation between cores.

Second, notable features of the MS record at these sites (and at Site 1101 , also on a sediment drift) are the narrow regions of steady, very low (probably "background") susceptibility, as shown in Figures F1 and F2 and (at higher magnification) in Figure F4 at $\sim 45$ mbsf. The remanent magnetic intensity (before demagnetization) is reduced over the same intervals (Shipboard Scientific Party, 1999b, tables T5, T11, T19; 1999c, tables T4, T8, T13). There is a correspondence between these lows and low values of the chromaticity parameters $\mathrm{a}^{*}$ and $\mathrm{b}^{*}$ in some but not all intervals.

The lows may be the result of diagenesis; however, it is clear (e.g., Fig. F4) that they occupy the same position and have the same form in the record from each hole (holes at a single site are typically only 10-20 m apart horizontally), and they have been used in the correlations described here. It would be unjustifiable to use them either for correlating between sites or in such activities as spectral analysis aimed at extracting paleoclimate variation, unless they could be shown to be primary or uniquely related to primary core features.

Figure F4 also illustrates core distortion. Correlation between cores from the two holes is generally very good. However, the upper part of Core $178-1096 \mathrm{~A}-6 \mathrm{H}$ is more expanded than the equivalent part of Core 178-1096B-6H (the upper $87 \mathrm{~cm}$ is recorded as disturbed by drilling: Shipboard Scientific Party, 1999c). In contrast, the region around 48 mbsf is relatively compressed in Core $178-1096 \mathrm{~A}-6 \mathrm{H}$, in a region remote from the end of the core in either hole. Differently again, part of the section appears to be omitted at the boundary between Cores 1781096B-5H and 6H (even though nominal recovery in both cores exceeds $100 \%$ ).

The existence of differential core distortion noted above indicates that care should be taken in determining the meters composite depth of samples from parts of cores not included in the optimal splice. It may be more precise to use a comparison of the MS records of the equivalent omitted and included cores rather than accept the computed composite depth of the omitted part.

\section{SUMMARY}

Composite depths have been calculated and optimal spliced sections produced for Sites 1095 and 1096, the shallower parts of which were multiple cored. The sites lie on a sediment drift on the continental rise off the Pacific margin of the Antarctic Peninsula. This work is intended to supersede provisional calculations achieved on board (Shipboard Scientific Party, 1999b, 1999c).

\section{ACKNOWLEDGMENTS}

I am grateful to those members of the shipboard scientific party and technical support team who acquired the data (MST and color scanner) used in this work. SPLICER V.2.1 was provided by the Borehole Research
F4. Comparison of magnetic susceptibility at Site 1096, p. 11.

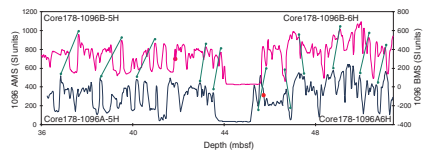


P.F. BARKER

DAta Report: Composite Depths AND SPliced Sections

Group at Lamont-Doherty Earth Observatory. The manuscript was improved as a result of comments from Gary Acton and an unnamed reviewer. 


\section{REFERENCES}

Curry, W.B., Shackleton, N.J., Richter, C., et al., 1995. Proc. ODP, Init. Repts., 154: College Station, TX (Ocean Drilling Program).

Feary, D.A., Hine, A.C., Malone, M.J., et al., 2000. Proc. ODP, Init. Repts., 182 [CDROM]. Available from: Ocean Drilling Program, Texas A\&M University, College Station, TX 77845-9547, U.S.A.

Gersonde, R., Hodell, D.A., Blum, P., et al., 1999. Proc. ODP, Init. Repts., 177 [CDROM]. Available from: Ocean Drilling Program, Texas A\&M University, College Station, TX 77845-9547, U.S.A.

Hagelberg, T., Shackleton, N., Pisias, N., and Shipboard Scientific Party, 1992. Development of composite depth sections for Sites 844 through 854. In Mayer, L., Pisias, N., Janecek, T., et al., Proc. ODP, Init. Repts., 138 (Pt. 1): College Station, TX (Ocean Drilling Program), 79-85.

Jansen, E., Raymo, M.E., Blum, P., et al., 1996. Proc. ODP, Init. Repts., 162: College Station, TX (Ocean Drilling Program).

Moran, K., 1997. Elastic property corrections applied to Leg 154 sediment, Ceara Rise. In Shackleton, N.J., Curry, W.B., Richter, C., and Bralower, T.J. (Eds.), Proc. ODP, Sci. Results, 154: College Station, TX (Ocean Drilling Program), 151-155.

Robinson, S.G., 1990. Applications for whole-core magnetic susceptibility measurements of deep-sea sediments: Leg 115 results. In Duncan, R.A., Backman, J., Peterson, L.C., et al., Proc. ODP, Sci. Results, 115: College Station, TX (Ocean Drilling Program), 737-771.

Ruddiman, W.F., Cameron, D., and Clement, B.M., 1987. Sediment disturbance and correlation of offset holes drilled with the hydraulic piston corer: Leg 94. In Ruddiman, W.F., Kidd, R.B., Thomas, E., et al., Init. Repts. DSDP, 94 (Pt. 2): Washington (U.S. Govt. Printing Office), 615-634.

Shipboard Scientific Party, 1999a. Explanatory notes. In Barker, P.F., Camerlenghi, A., Acton, G.D., et al., Proc. ODP, Init. Repts., 178, 1-66 [CD-ROM]. Available from: Ocean Drilling Program, Texas A\&M University, College Station, TX 77845-9547, U.S.A.

, 1999b. Site 1095. In Barker, P.F., Camerlenghi, A., Acton, G.D., et al., Proc. ODP, Init. Repts., 178, 1-173 [CD-ROM]. Available from: Ocean Drilling Program, Texas A\&M University, College Station, TX 77845-9547, U.S.A.

, 1999c. Site 1096. In Barker, P.F., Camerlenghi, A., Acton, G.D., et al., Proc. ODP, Init. Repts., 178, 1-144 [CD-ROM]. Available from: Ocean Drilling Program, Texas A\&M University, College Station, TX 77845-9547, U.S.A.

Wang, P., Prell, W.L., Blum, P., et al., 2000. Proc. ODP, Init. Repts., 184 [CD-ROM]. Available from: Ocean Drilling Program, Texas A\&M University, College Station, TX 77845-9547, USA. 
P.F. BARKER

DAta Report: Composite Depths ANd SPliced Sections

Figure F1. Magnetic susceptibility (MS) for Holes 1095A, 1095B, 1095D, and the spliced sections plotted against depth to 90 mcd (labeled A, B, D, and Spl, respectively). Colors of the spliced MS curve reflect the origins of the spliced sections. The MS scale is correct for values from Hole 1095A; values for other holes and the spliced sections are offset to aid comparison.

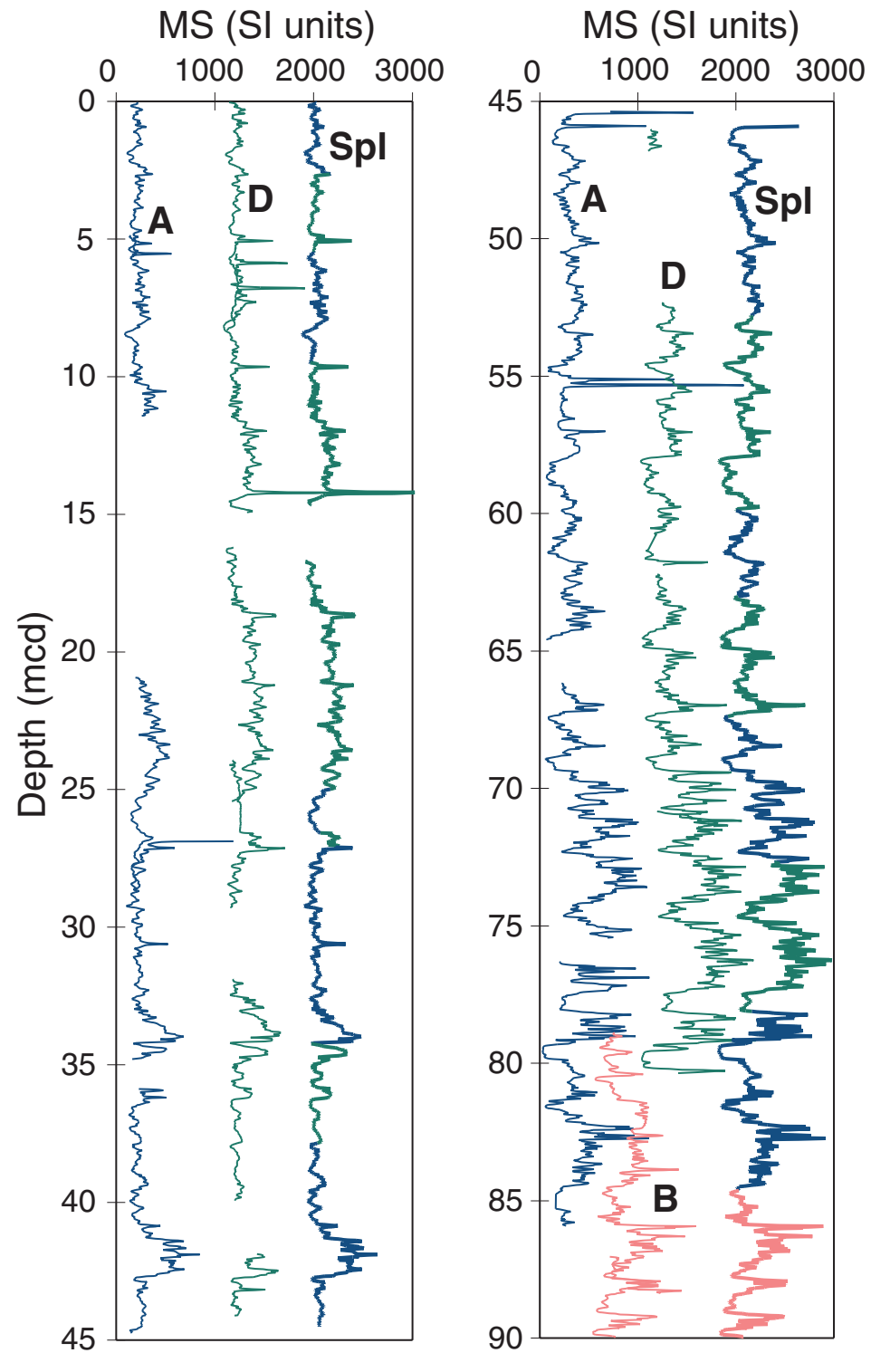


Figure F2. Magnetic susceptibility (MS) for Holes 1096A, 1096B, 1096C, and the spliced sections plotted against depth to 270 mcd (labeled A, B, $\mathrm{C}$, and Spl, respectively). Colors of the spliced MS curve reflect the origins of the spliced sections. The MS scale is correct for values from Hole 1096A; values for other holes and the spliced sections are offset to aid comparison.
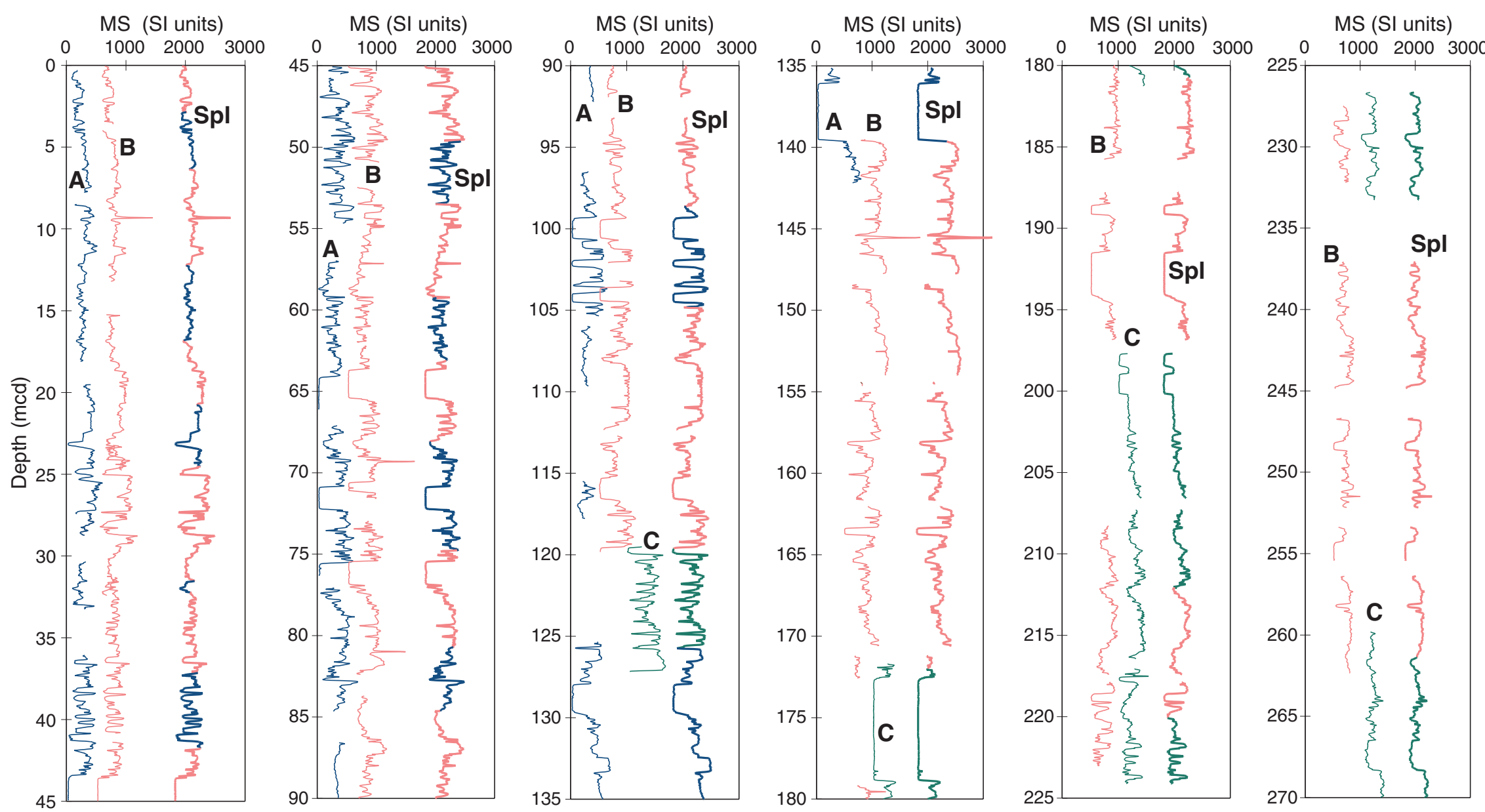
P.F. BARKER

DAta Report: Composite Depths ANd SPliced Sections

Figure F3. Core offsets applied at Sites 1095 and 1096 plotted against depth. Site 1095 offsets are solid circles $($ Hole 1095 A = blue, Hole 1095B = pink, Hole 1095D = green), and Site 1096 offsets are solid squares $($ Hole 1096A = blue, Hole 1096B = pink, Hole 1096C = green).

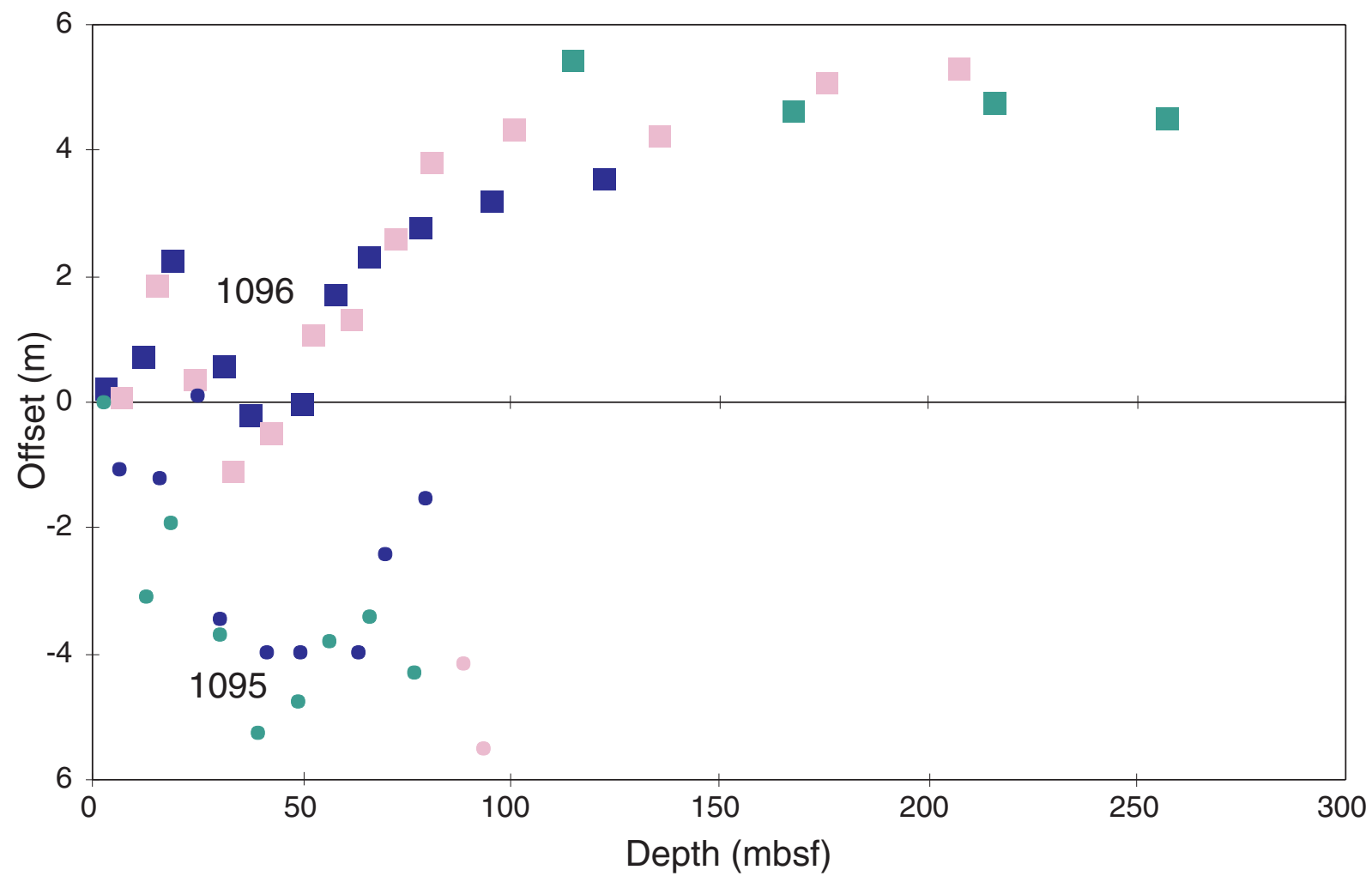




\section{P.F. BARKER}

Figure F4. Comparison of magnetic susceptibility (MS) between 36 and $51 \mathrm{mbsf}$ at Site 1096. Hole 1096A $=$ blue, Hole $1096 \mathrm{~B}=$ pink. Red circles $=$ positions of core boundaries, green lines = specimen correlations. Note the low MS values in both holes around 45 mbsf.

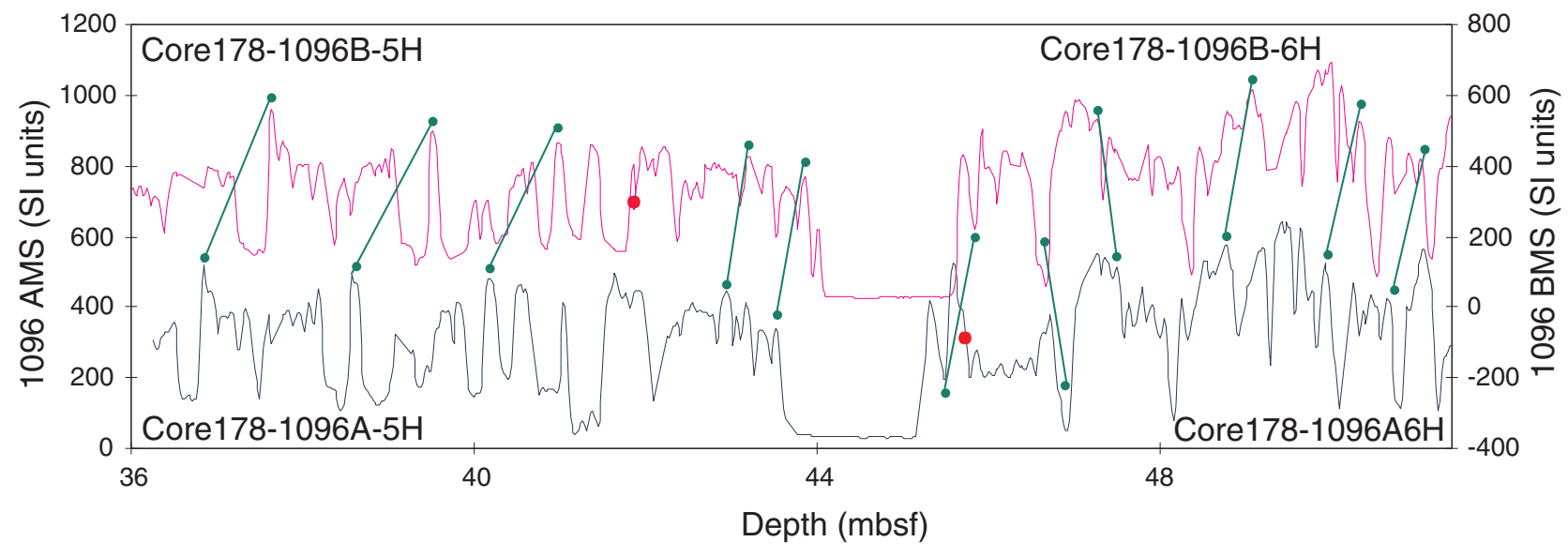


P.F. BARKER

DAtA Report: CoMposite DePthS AND SPLiCEd SECTIONS

Table T1. Offsets of cores, Holes 1095A, 1095B, and $1095 \mathrm{D}$.

\begin{tabular}{|c|c|c|c|}
\hline Core & $\begin{array}{c}\text { Top } \\
\text { depth } \\
\text { (mbsf) }\end{array}$ & $\begin{array}{l}\text { Offset } \\
\text { (m) }\end{array}$ & $\begin{array}{c}\text { Top } \\
\text { depth } \\
\text { (mcd) }\end{array}$ \\
\hline \multicolumn{4}{|c|}{ 178-1095A- } \\
\hline $1 \mathrm{H}$ & 0 & 0 & 0 \\
\hline $2 \mathrm{H}$ & 5.9 & -1.06 & 4.84 \\
\hline $3 \mathrm{H}$ & 11.3 & -1.2 & 10.1 \\
\hline $4 \mathrm{H}$ & 20.8 & 0.1 & 20.9 \\
\hline $5 \mathrm{H}$ & 30.3 & -3.46 & 26.84 \\
\hline $6 \mathrm{H}$ & 39.8 & -3.96 & 35.84 \\
\hline $7 \mathrm{H}$ & 49.3 & -3.96 & 45.34 \\
\hline $8 \mathrm{H}$ & 58.8 & -3.96 & 54.84 \\
\hline $9 \mathrm{H}$ & 68.3 & -2.42 & 65.88 \\
\hline $10 \mathrm{H}$ & 77.8 & -1.54 & 76.26 \\
\hline \multicolumn{4}{|c|}{ 178-1095B- } \\
\hline $1 \mathrm{H}$ & 83 & -4.14 & 78.86 \\
\hline $2 \mathrm{H}$ & 92.5 & -5.5 & 87 \\
\hline \multicolumn{4}{|c|}{ 178-1095D- } \\
\hline $1 \mathrm{H}$ & 0 & 0 & 0 \\
\hline $2 \mathrm{H}$ & 8.6 & -3.1 & 5.5 \\
\hline $3 \mathrm{H}$ & 18.1 & -1.92 & 16.18 \\
\hline $4 \mathrm{H}$ & 27.6 & -3.7 & 23.9 \\
\hline $5 \mathrm{H}$ & 37.1 & -5.24 & 31.86 \\
\hline $6 \mathrm{H}$ & 46.6 & -4.76 & 41.84 \\
\hline $7 \mathrm{H}$ & 56.1 & -3.8 & 52.3 \\
\hline $8 \mathrm{H}$ & 65.6 & -3.42 & 62.18 \\
\hline $9 \mathrm{H}$ & 75.1 & -4.3 & 70.8 \\
\hline
\end{tabular}

Note: This table is also available in ASCII format. 
P.F. BARKER

Data Report: Composite Depths and SPliced Sections

Table T2. Offsets of cores, Holes 1096A, 1096B, and 1096C.

\begin{tabular}{|c|c|c|c|}
\hline Core & $\begin{array}{c}\text { Top } \\
\text { depth } \\
\text { (mbsf) }\end{array}$ & $\begin{array}{l}\text { Offset } \\
(\mathrm{m})\end{array}$ & $\begin{array}{l}\text { Top } \\
\text { depth } \\
\text { (mcd) }\end{array}$ \\
\hline \multicolumn{4}{|c|}{ 178-1096A- } \\
\hline $1 \mathrm{H}$ & 0 & 0.24 & 0.24 \\
\hline $2 \mathrm{H}$ & 7.7 & 0.74 & 8.44 \\
\hline $3 \mathrm{H}$ & 17.2 & 2.26 & 19.46 \\
\hline $4 \mathrm{H}$ & 26.7 & 0.59 & 27.29 \\
\hline $5 \mathrm{H}$ & 36.2 & -0.19 & 36.01 \\
\hline $6 \mathrm{H}$ & 45.7 & 0.01 & 45.71 \\
\hline $7 \mathrm{H}$ & 55.2 & 1.73 & 56.93 \\
\hline $8 \mathrm{H}$ & 64.7 & 2.35 & 67.05 \\
\hline $9 \mathrm{H}$ & 74.2 & 2.81 & 77.01 \\
\hline $10 \mathrm{H}$ & 83.7 & 2.81 & 86.51 \\
\hline $11 \mathrm{H}$ & 93.2 & 3.23 & 96.43 \\
\hline $12 \mathrm{H}$ & 102.7 & 3.23 & 105.93 \\
\hline $13 \mathrm{H}$ & 112.2 & 3.23 & 115.43 \\
\hline $14 \mathrm{H}$ & 121.7 & 3.58 & 125.28 \\
\hline $15 \mathrm{H}$ & 131.2 & 3.88 & 135.08 \\
\hline \multicolumn{4}{|c|}{ 178-1096B- } \\
\hline $1 \mathrm{H}$ & 0 & 0 & 0 \\
\hline $2 \mathrm{H}$ & 3.8 & 0.12 & 3.92 \\
\hline $3 \mathrm{H}$ & 13.3 & 1.88 & 15.18 \\
\hline $4 \mathrm{H}$ & 22.8 & 0.38 & 23.18 \\
\hline $5 \mathrm{H}$ & 32.3 & -1.05 & 31.25 \\
\hline $6 \mathrm{H}$ & 41.8 & -0.47 & 41.33 \\
\hline $7 \mathrm{H}$ & 51.3 & 1.11 & 52.41 \\
\hline $8 \mathrm{H}$ & 60.8 & 1.35 & 62.15 \\
\hline $9 \mathrm{H}$ & 70.3 & 2.61 & 72.91 \\
\hline $10 \mathrm{H}$ & 79.8 & 3.85 & 83.65 \\
\hline $11 \mathrm{H}$ & 89.3 & 3.85 & 93.15 \\
\hline $12 \mathrm{H}$ & 98.8 & 4.35 & 103.15 \\
\hline $13 \mathrm{H}$ & 108.3 & 4.35 & 112.65 \\
\hline $16 \mathrm{H}$ & 135.2 & 4.26 & 139.46 \\
\hline $17 \mathrm{H}$ & 144.1 & 4.26 & 148.36 \\
\hline $18 \mathrm{H}$ & 150.1 & 4.26 & 154.36 \\
\hline $19 \mathrm{H}$ & 150.7 & 4.26 & 154.96 \\
\hline $20 \mathrm{H}$ & 157.7 & 4.26 & 161.96 \\
\hline $22 x$ & 166.9 & 4.26 & 171.16 \\
\hline $23 x$ & 174 & 5.12 & 179.12 \\
\hline $24 X$ & 183.6 & 4.12 & 187.72 \\
\hline $26 X$ & 202.9 & 5.32 & 208.22 \\
\hline $27 X$ & 212.5 & 5.32 & 217.82 \\
\hline $28 X$ & 222.1 & 5.32 & 227.42 \\
\hline $29 X$ & 231.7 & 5.32 & 237.02 \\
\hline $30 x$ & 241.3 & 5.32 & 246.62 \\
\hline $31 x$ & 248 & 5.32 & 253.32 \\
\hline $32 x$ & 251 & 5.32 & 256.32 \\
\hline \multicolumn{4}{|c|}{ 178-1096C- } \\
\hline $1 \mathrm{H}$ & 114 & 5.45 & 119.45 \\
\hline $2 \mathrm{H}$ & 167 & 4.64 & 171.64 \\
\hline $3 x$ & 193 & 4.64 & 197.64 \\
\hline $4 X$ & 202.6 & 4.64 & 207.24 \\
\hline $5 x$ & 212.2 & 4.8 & 217 \\
\hline $6 X$ & 221.8 & 4.8 & 226.6 \\
\hline $7 X$ & 255.2 & 4.54 & 259.74 \\
\hline $8 x$ & 260.9 & 5.54 & 266.44 \\
\hline
\end{tabular}

Note: This table is also available in ASCII format. 
P.F. BARKER

DAta Report: Composite Depths AND SPliced Sections

Table T3. Splice tie points used to create spliced sections, Site 1096.

\begin{tabular}{|c|c|c|c|c|c|c|}
\hline $\begin{array}{l}\text { Core, section, } \\
\text { interval }(\mathrm{cm})\end{array}$ & $\begin{array}{l}\text { Depth } \\
\text { (mbsf) }\end{array}$ & $\begin{array}{l}\text { Composite } \\
\text { depth } \\
\text { (mcd) }\end{array}$ & $\begin{array}{l}\text { Linked } \\
\text { by }\end{array}$ & $\begin{array}{l}\text { Core, section, } \\
\text { interval }(\mathrm{cm})\end{array}$ & $\begin{array}{l}\text { Depth } \\
\text { (mbsf) }\end{array}$ & $\begin{array}{c}\text { Composite } \\
\text { depth } \\
\text { (mcd) }\end{array}$ \\
\hline $178-$ & & & & 78- & & \\
\hline 1095A-1H-2, 119 & 2.65 & 2.65 & Tie & 1095D-1H-2, 115 & 2.65 & 2.65 \\
\hline 1095D-1H-4, 97 & 5.47 & 5.47 & Tie & $1095 \mathrm{~A}-2 \mathrm{H}-1,63$ & 6.53 & 5.47 \\
\hline $1095 \mathrm{~A}-2 \mathrm{H}-4,15$ & 10.55 & 9.49 & Tie & 1095D-2H-3, 99 & 12.59 & 9.49 \\
\hline 1095D-2H-7, 17 & 17.77 & 14.67 & Tie & 1095A-3H-4, 97 & 15.87 & 14.67 \\
\hline $1095 \mathrm{~A}-3 \mathrm{H}-6,112$ & 17.9 & 16.7 & Tie & 1095D-3H-1, 52 & 18.62 & 16.7 \\
\hline 1095D-3H-6, 131 & 26.91 & 24.99 & Tie & $1095 \mathrm{~A}-4 \mathrm{H}-3,109$ & 24.89 & 24.99 \\
\hline 1095A-4H-4, 117 & 26.47 & 26.57 & Tie & 1095D-4H-2, 117 & 30.27 & 26.57 \\
\hline 1095D-4H-3, 19 & 30.79 & 27.09 & Tie & $1095 \mathrm{~A}-5 \mathrm{H}-1,25$ & 30.55 & 27.09 \\
\hline 1095A-5H-5, 139 & 37.69 & 34.23 & Tie & 1095D-5H-2, 87 & 39.47 & 34.23 \\
\hline 1095D-5H-4, 147 & 43.07 & 37.83 & Tie & 1095A-6H-2, 49 & 41.79 & 37.83 \\
\hline 1095A-6H-6, 117 & 48.47 & 44.51 & Tie & 1095D-6H-3, 37 & 49.27 & 44.51 \\
\hline 1095D-6H-4, 27 & 50.67 & 45.91 & Tie & 1095A-7H-1, 57 & 49.87 & 45.91 \\
\hline 1095A-7H-5, 145 & 56.75 & 52.79 & Tie & 1095D-7H-1, 49 & 56.59 & 52.79 \\
\hline 1095D-7H-6, 9 & 63.69 & 59.89 & Tie & $1095 \mathrm{~A}-8 \mathrm{H}-4,55$ & 63.85 & 59.89 \\
\hline $1095 \mathrm{~A}-8 \mathrm{H}-6,69$ & 66.99 & 63.03 & Tie & 1095D-8H-1, 85 & 66.45 & 63.03 \\
\hline 1095D-8H-4, 69 & 70.79 & 67.37 & Tie & 1095A-9H-1, 149 & 69.79 & 67.37 \\
\hline 1095A-9H-5, 81 & 75.11 & 72.69 & Tie & 1095D-9H-2, 39 & 76.99 & 72.69 \\
\hline 1095D-9H-5, 131 & 82.41 & 78.11 & Tie & $1095 \mathrm{~A}-10 \mathrm{H}-2,35$ & 79.65 & 78.11 \\
\hline $1095 \mathrm{~A}-10 \mathrm{H}-6,87$ & 86.17 & 84.63 & Tie & 1095B-1H-4, 127 & 88.77 & 84.63 \\
\hline 1095B-1H-7, 3 & 92.03 & 87.89 & Tie & 1095B-2H-1, 89 & 93.39 & 87.89 \\
\hline 1095B-2H-6, 67 & 100.67 & 95.17 & Append & 1095B-3Н-1, 0 & 102 & 96.5 \\
\hline
\end{tabular}

Note: This table is also available in ASCII format. 
P.F. BARKER

DAta Report: Composite Depths AND SPliced Sections

Table T4. Splice tie points used to create spliced sections, Site 1096.

\begin{tabular}{|c|c|c|c|c|c|c|}
\hline $\begin{array}{l}\text { Core, section, } \\
\text { interval }(\mathrm{cm})\end{array}$ & $\begin{array}{l}\text { Depth } \\
\text { (mbsf) }\end{array}$ & $\begin{array}{l}\text { Composite } \\
\text { depth } \\
\text { (mcd) }\end{array}$ & $\begin{array}{l}\text { Linked } \\
\text { by }\end{array}$ & $\begin{array}{l}\text { Core, section, } \\
\text { interval }(\mathrm{cm})\end{array}$ & $\begin{array}{l}\text { Depth } \\
\text { (mbsf) }\end{array}$ & $\begin{array}{c}\text { Composite } \\
\text { depth } \\
\text { (mcd) }\end{array}$ \\
\hline $178-$ & & & & 78- & & \\
\hline 1096B-1H-2, 136 & 2.86 & 2.86 & Tie & 1096A-1H-2, 112 & 2.62 & 2.86 \\
\hline 1096A-1H-5, 12 & 6.12 & 6.36 & Tie & 1096B-2H-2, 94 & 6.24 & 6.36 \\
\hline 1096B-2H-6, 88 & 12.12 & 12.24 & Tie & $1096 \mathrm{~A}-2 \mathrm{H}-3,80$ & 11.5 & 12.24 \\
\hline 1096A-2H-6, 90 & 16.1 & 16.84 & Tie & 1096B-3H-2, 16 & 14.96 & 16.84 \\
\hline 1096B-3H-4, 110 & 18.9 & 20.78 & Tie & 1096A-3H-1, 132 & 18.52 & 20.78 \\
\hline 1096A-3H-4, 56 & 22.26 & 24.52 & Tie & 1096B-4H-1, 134 & 24.14 & 24.52 \\
\hline 1096B-4H-7, 70 & 31.15 & 31.53 & Tie & 1096A-4H-3, 124 & 30.94 & 31.53 \\
\hline 1096A-4H-4, 44 & 31.64 & 32.23 & Tie & 1096B-5H-1, 98 & 33.28 & 32.23 \\
\hline 1096B-5H-4, 140 & 38.2 & 37.15 & Tie & 1096A-5H-1, 114 & 37.34 & 37.15 \\
\hline $1096 \mathrm{~A}-5 \mathrm{H}-4,124$ & 41.94 & 41.75 & Tie & 1096B-6H-1, 42 & 42.22 & 41.75 \\
\hline 1096B-6H-6, 82 & 50.12 & 49.65 & Tie & 1096A-6H-3, 94 & 49.64 & 49.65 \\
\hline 1096A-6H-6, 28 & 53.48 & 53.49 & Tie & 1096B-7H-1, 108 & 52.38 & 53.49 \\
\hline 1096B-7H-5, 92 & 58.16 & 59.27 & Tie & 1096A-7H-2, 84 & 57.54 & 59.27 \\
\hline 1096A-7H-5, 16 & 61.36 & 63.09 & Tie & 1096B-8H-1, 94 & 61.74 & 63.09 \\
\hline 1096B-8H-4, 144 & 66.74 & 68.09 & Tie & 1096A-8H-1, 104 & 65.74 & 68.09 \\
\hline 1096A-8H-6, 22 & 72.42 & 74.77 & Tie & 1096B-9H-2, 36 & 72.16 & 74.77 \\
\hline 1096В-9H-6, 30 & 78.1 & 80.71 & Tie & 1096A-9H-3, 70 & 77.9 & 80.71 \\
\hline 1096A-9H-6, 134 & 81.82 & 84.63 & Tie & 1096B-10H-1, 98 & 80.78 & 84.63 \\
\hline 1096B-10H-6, 78 & 88.08 & 91.93 & Append & 1096B-11H-1, 0 & 89.3 & 93.15 \\
\hline 1096B-11H-4, 100 & 94.8 & 98.65 & Tie & 1096A-11H-2, 72 & 95.42 & 98.65 \\
\hline $1096 \mathrm{~A}-11 \mathrm{H}-6,88$ & 101.58 & 104.81 & Tie & 1096B-12H-2, 16 & 100.46 & 104.81 \\
\hline 1096B-12H-7, 18 & 107.98 & 112.33 & Append & 1096B-13H-1, 0 & 108.3 & 112.65 \\
\hline 1096B-13H-5, 98 & 115.28 & 119.63 & Tie & 1096C-1H-1, 18 & 114.18 & 119.63 \\
\hline 1096C-1H-6, 52 & 120.27 & 125.72 & Tie & 1096A-14H-1, 44 & 122.14 & 125.72 \\
\hline 1096A-14H-7, 72 & 131.42 & 135 & Append & 1096A-15H-1, 0 & 131.2 & 135.08 \\
\hline $1096 \mathrm{~A}-15 \mathrm{H}-4,6$ & 135.76 & 139.64 & Tie & 1096B-16H-1, 18 & 135.38 & 139.64 \\
\hline 1096B-16H-6, 78 & 143.48 & 147.74 & Append & 1096B-17H-1, 0 & 144.1 & 148.36 \\
\hline 1096B-17H-4, 112 & 149.72 & 153.98 & Append & 1096B-18H-1, 0 & 150.1 & 154.36 \\
\hline 1096B-18H-1, 18 & 150.28 & 154.54 & Append & 1096B-19H-1, 0 & 150.7 & 154.96 \\
\hline 1096B-19H-5, 70 & 157.4 & 161.66 & Append & 1096B-20H-1, 0 & 157.7 & 161.9 \\
\hline 1096B-20H-6, 112 & 166.32 & 170.58 & Append & 1096B-22X-1, 0 & 166.9 & 171.16 \\
\hline 1096B-22X-1, 88 & 167.78 & 172.04 & Tie & $1096 \mathrm{C}-2 \mathrm{H}-1,40$ & 167.4 & 172.04 \\
\hline 1096C-2H-6, 134 & 176.1 & 180.74 & Tie & 1096B-23H-2, 11 & 175.62 & 180.74 \\
\hline 1096B-23X-5, 74 & 180.64 & 185.76 & Append & 1096B-24H-1, 0 & 183.6 & 187.72 \\
\hline 1096B-24X-7, 38 & 192.71 & 196.83 & Append & 1096C-3X-1, 0 & 193 & 197.64 \\
\hline 1096C-3X-6, 142 & 201.92 & 206.56 & Append & 1096C-4X-1, 0 & 202.6 & 207.24 \\
\hline $1096 C-4 X-4,36$ & 207.46 & 212.1 & Tie & 1096B-26H-3, 88 & 206.78 & 212.1 \\
\hline 1096B-26X-7, 18 & 212.08 & 217.4 & Append & 1096B-27H-1, 0 & 212.5 & 217.82 \\
\hline 1096B-27X-2, 76 & 214.76 & 220.08 & Tie & $1096 C-5 X-3,8$ & 215.28 & 220.08 \\
\hline 1096C-5X-5, 112 & 219.32 & 224.12 & Append & 1096C-6X-1, 0 & 221.8 & 226.6 \\
\hline 1096C-6X-5, 66 & 228.46 & 233.26 & Append & 1096B-29X-1, 0 & 231.7 & 237.02 \\
\hline 1096B-29X-6, 34 & 239.54 & 244.86 & Append & 1096B-30X-1, 0 & 241.3 & 246.62 \\
\hline 1096B-30X-4, 104 & 246.84 & 252.16 & Append & 1096B-31X-1, 0 & 248 & 253.3 \\
\hline 1096B-31X-2, 60 & 250.1 & 255.42 & Append & 1096B-32X-1, 0 & 251 & 256.32 \\
\hline 1096B-32X-4, 56 & 256.06 & 261.38 & Tie & 1096C-7X-2, 14 & 256.84 & 261.38 \\
\hline 1096C-7X-5, 70 & 261.9 & 266.44 & Append & 1096C-8X-1, 0 & 260.9 & 266.44 \\
\hline
\end{tabular}

Note: This table is also available in ASCII format. 